\title{
Attitudes on Financial Reporting Issues: An Australian
}

\section{Study}

\author{
Gregory Kenneth Laing (Corresponding author) \\ Faculty of Business, University of the Sunshine Coast \\ Maroochydore DC Qld 4558 Australia \\ Email: glaing@usc.edu.au, Telphone:+61 754594675
}

\author{
Ronald William Perrin \\ School of Accounting \& Finance, Faculty of Commerce \\ University of Wollongong, Wollongong NSW 2522 Australia
}

Received: August 14, 2011 Accepted: September 06, 2011 DOI: 10.5296/ijafr.v1i1.856

\begin{abstract}
The aim of this research was to test the attitudes of professional accountants with regards to financial reporting issues. Given the changes arising from the adoption of the International Accounting Standards the expectation was that problems identified by prior research would have been mitigated. Surveys were conducted of accounting professionals using the questionnaire instrument designed by Francia and Strawser (1971). The data were collated and processed to determine the perceived information deficiency and importance of the various aspects of financial reporting. The major items in which information was considered to be deficient were - timing of revenue recognition, income tax effect accounting, executory contracts and treatment of prior period adjustments. By contrast the most important items were found to be uniformity in financial reporting, income tax effect accounting, use of fair market values, definition of equity versus liability and treatment of prior period adjustments. The findings have implications for the future development of accounting standards. Greater guidance should be given to explaining the practice, applications and consequences of the accounting standards on financial reporting. This paper provides a valuable insight into the perceived deficiencies of information on items that affect financial reporting by accountants in the Australian environment and adds a new perspective to the evaluation of adoption of international accounting standards.
\end{abstract}

Keywords: International accounting standards, financial reporting, Australia. 


\section{Introduction}

In January 2005 Australia adopted the International Accounting Standards, now known as the International Financial Reporting Standards, as the basis for the issue of the Australian Accounting Standards. The decision to implement this sweeping change had been reached by the Financial Reporting Council in Australia in July 2002, and resulted in unprecedented change in the control over the financial reporting requirements in Australia (Deegan, 2010; Brown \& Tarca, 2005). Effectively, the decision meant that all Australian Accounting Standards would be determined by the International Accounting Standards Board not by an Australian Accounting Standards Board.

The adoption resulted in a number of significant changes in some accounting standards. For example, the treatment of intangible assets changed dramatically with items such as research, brand names mastheads being expensed as incurred; other intangible assets could only be revalued if there was an active market; goodwill was subjected to an annual impairment test; revaluation of property plant and equipment was to be done on an asset-by-asset basis; the term revenue was restricted to inflows from ordinary activities; prior period errors were to be adjusted retrospectively against opening equity balances; the test for classifying items as equity or liabilities changed to a more restrictive form (Deegan, 2010; Wines, Dagwell \& Windsor, 2007). As a result of these dramatic changes the accounting profession in Australia had to deal with a variety of concerns about the financial reports that emanated from the 2005 conversion (Haswell \& Langfield-Smith, 2008). Among the sceptics was a large proportion of financial accounting professionals.

The accounting literature had prior to 2005 been actively questioning and providing guidance on the evolution of accounting standards in the Australian context (Watts \& Zimmerman, 1978: Hines, 1989), after that date the focus changed since the standards were adopted without any facility for question about their efficacy to the Australian context. In deed the very nature of the education process both at the professional level and at the university level acquiesced to the changes as if this transformation was a natural course of events. Little attention has been given to exploring the attitudes of those involved in implementing and following the accounting standards. In deed the literature appears to reflect the belief that the professional accountants have simply accepted the changes, and are even less inclined to question the relevance of the adoption of international accounting standards because of the rhetoric pertaining to the benefits of a global economy (Chand \& White, 2007; Whittington, 2005).

This paper addresses this gap in the literature by undertaking an empirical study of the attitudes towards the financial accounting reporting standards in Australia of professional accountants in Australia. 


\section{Literature Review}

The problems associated with financial reporting have mostly been linked to the various accounting standards (Collett, Godfrey \& Hrasky, 1998). For the most part complaints regarding deficiencies in accounting standards have been most vocal following prominent corporate collapses (Cooper \& Deo, 2005). The response from the Australian Federal Government to the major corporate collapses such as HIH and One-tel was to increase the legislative requirements pertaining to auditing and this lead to the Australian Commonwealth Treasury's Corporate Law Economic Reform Program (CLERP) which lead to radical draft legislative reforms similar to those emanating from the Sarbanes Oxley Act in the USA (Collett, Godfrey \& Hrasky, 1998; Brown \& Tarca, 2005). For the most part the decisions were made with very limited input from the rank and file accounting practitioners.

The concept of seeking input from rank and file practitioners can be traced back to the early work of Francia and Strawser (1971) in which they surveyed 300 members of the American Accounting Association and in so doing established the potential usefulness of studies into attitudes of accountants. They suggested that unless the general perceptions of the providers of financial information could be established and monitored efforts to improve or change financial reporting could be misdirected. Under the heading of general considerations the most deficient items were timing of revenue recognition, definition of income, comparability in financial reporting. Under the heading of current problems items identified as being most deficient and most important were, operations of conglomerates, accounting for business combinations, and calculation of earnings per share. Under the heading proposals for improved financial reporting the items identified as being most important and most deficient were current or market values, effects of price level changes, disclosure of rate of return on investment. Trump and Hendrickson (1971) used the same questionnaire to survey 300 members of the American Institute of Certified Public Accountants. The findings in both studies identified a similarity in attitudes towards problems considered to be current issues in accounting and financial reporting at that time.

A further development on this theme came from Francia and Strawser (1972) in which they surveyed accountants in private industry and found that their attitudes on the issues of financial reporting problems were correlated with accountants in public practice. Under the heading of general considerations the most deficient items were objectivity in financial reporting, comparability in financial reporting, and timing of revenue recognition. Under the heading of current problems items identified as being most deficient and most important were, operations of conglomerates, accounting for business combinations, and accounting for intangibles. Under the heading proposals for improved financial reporting the items identified as being most important and most deficient were accounting for human resources, effects of price level changes, and disclosure of rate of return on investment.

When the study was repeated by Francia, Grossman and Strawser (1978) they found a general decline in the importance for five of the seven financial reporting problems and this was interpreted to be an indication that the efforts to improve financial reporting, in that 6 year period, may have resulted in the change. They concluded that the findings suggested that of 
those accountants surveyed (p.40) "... their perceptions, as reported, are somewhat optimistic and encouraging." Of course one of the areas of interest in this study is to compare the perceived relevance of issues between the American and the Australian profession. Perceived relevance is operationalised by using the mean values of part (c) "importance" and part (d) "perceived defficiency". This should offer some assessment concerning the conceptual framework in Australia, in general whether the accountants are satisfied with the progress todate.

Francia and Strawser (1971,1972), Francia,Grossman and Strawser (1978) and Trump and Hendrickson (1971) used almost identical questionnaires to study attitudes to financial reporting issues. There were a number of topics found to be considered as "current financial reporting problems" and these problems were consistently rated as having a high degree of significance for the accounting and management subjects. This is an issue addressed in the current study due to the change to international accounting standards as part of the establishment of the global economy.

The purpose of this study was to measure attitudes toward financial accounting issues to assess the impact of any changes to the financial reporting requirements as a consequence of the adoption of the International Accounting Standards in the Australian accounting context.

\section{Method}

\subsection{Subjects}

The names and addresses of 200 accountants in public practice were selected, at random, from the locality directory of the Australian Society of CPA's and Institute of Chartered Accountants contained in the 2007 Yellow pages Sydney and Brisbane area telephone books. Professional accountants in public practice were selected as it was considered that they would be knowledgeable of the issues raised and should have a well developed attitude to most of the questions asked in the survey.

There are limitations associated with the use of questionnaire surveys for the acquisition of data. These may be summarised in terms of: the 'halo' effect, common method measurement errors, scaling issues, non response bias, and general issues of questionnaire understandability and reliability (Dane, 1990). These limitations were addressed by using an instrument which had been previously tested and had been designed specifically for use with members of the accounting profession. The non response bias, was addressed by way of an analysis of late returns which showed no significant difference, in the accountants responses at the 0.05 level using the Students " $\mathrm{t}$ " test. The second request responses were subsequently added to the sample. The total response rate was 21\%, Nachmias and Nachmias (1976) indicated that a response rate of between $20 \%$ and $40 \%$ was considered to be satisfactory.

\subsection{Attitudes}

Watson (1974) argued that studies aimed at identifying the differences in attitudes between groups need to establish that attitudes are representative of behaviour. For the most part 
Watson (1974) suggested that prior studies had mostly measured the cognitive component of attitude related to beliefs and/or opinions. In this study the beliefs and/or opinions are considered to be an important indicator of the relationship between accounting students and accounting practitioners. Whilst behaviour can not be predicted from the data acquired in this study, it may be possible to detect some predisposition that could influence behaviour. If for example, accountants have a negative attitude on the use of a particular issue it may be that at some time they will reject or disregard directives on that method of dealing with such accounting matters.

Statt (1981) defined attitude as: "A stable, long-lasting, learned predisposition to respond to certain things in a certain way. The concept has a cognitive (belief) aspect, an affective (feeling) aspect, and a connotative (action) aspect." In summary, an attitude may be described as a hypothetical construct, used to explain some consistency in patterns of human behaviour. The construct is hypothetical in that it does not physically exist, but its existence may be measured indirectly and separately from the physical reality.

\subsection{Instrument}

The instrument used in this study is a questionnaire which utilises a Likert Scale structured to provide a measure of the subjects attitude \&/or perception on the various questions in financial accounting. The questionnaire was adapted by Francia and Strawser (1971) from the format used by Porter (1962) to measure the perceived deficiencies in need fulfilment of managers. The order in which the questions appear on the questionnaire instrument was done so that the subjects would concentrate on the one aspect without being distracted thus providing a more consistent and focused response.

The Likert Scale has been evaluated to establish its validity for use in determining subjects beliefs and attitudes. Cooper (1976) suggested the use of a table of critical values for small samples and a normal approximation for large samples. Hsu (1979) suggested refinements to overcome limitations of the test proposed by Cooper. But both agreed that a table of critical values could be used to determine whether a Likert scale indicated significant agreement or disagreement.

The questionnaire was developed from the format first used by Francia and Strawser (1971) with two differences. Firstly, the questions in this survey were arranged in order of topic/category and not randomly dispersed. Secondly, an additional category entitled 'other problems in financial reporting' was added to encompass six new items relating to financial reporting. The four categories and questions were - general considerations in financial reporting, current problems in financial reporting, proposals for improved financial reporting, other problems in financial reporting.

In addition each question had three standard parts which the respondent was asked to provide a response rate on a scale of 1 to 7 . The rating scale was arranged with the low numbers representing minimum amounts and the high numbers maximum amounts. 
Part (a) How much is there now ?

This question was focusing on measuring the respondents perception of the current level of information in financial statements regarding a particular item/question.

Part (b) How much should there be ?

This question was aimed at measuring the respondents attitude with regards to the level of information that was in their opinion desirable.

Part (c) How important is this in your opinion?

This question was intended to provide additional information regarding the perceived level of importance associated with each item.

The approach adopted to measure perceived deficiencies was to follow the same method employed by Copeland, Francia and Strawser (1973, p.369). The technique used involves subtracting the response for part (a) from that of part (b). Thus creating an additional item which is introduced into the results, part (d) which measures the perceived "information deficiency". The formula is therefore expressed as an algebraic equation [b-a $=d]$. This derived outcome is then interpreted as indicating dissatisfaction when the number is positive, and the larger the number the greater the dissatisfaction with financial reporting practices. Porter (1967) devised this technique for the measurement of perceived deficiencies in need fulfillment of employees and the method was adopted in the earlier study.

\section{Results}

Interpretation of the results is based upon the level of the average mean values of the response to the individual items. For example, in regards to information deficiency the higher the average mean value the greater the deficiency and this approach applies equally to interpreting the level of importance.

In regards to the responses under the heading of general considerations presented in Table 1 the most deficient items were timing of revenue recognition, generally accepted accounting principles, and definition of income (revenue). Interestingly, the item uniformity in financial reporting is the most highly important however the information regarding this was not considered deficient. The most important item was uniformity in financial reporting which may indicate that even with the number of accounting standards there is still a need to achieve uniformity overall in financial reporting. 
Table 1. General Considerations in Financial Reporting Problems

\begin{tabular}{||l|l|l||}
\hline & $\begin{array}{l}\text { Information } \\
\text { deficiency }\end{array}$ & Importance \\
\hline $\begin{array}{l}\text { Generally Accepted Accounting Principles } \\
\text { Comparability in Financial Reporting }\end{array}$ & 1.5 & 4.7 \\
Consistency in Financial Reporting & 0.8 & 4.1 \\
Uniformity in Financial Reporting & 1.0 & 4.5 \\
Objectivity in Financial Reporting & 0.8 & 5.2 \\
Definition of Income (Revenue) & 1.1 & 4.4 \\
The Timing of Revenue recognition & 1.3 & 4.9 \\
\hline
\end{tabular}

Under the heading of current problems presented in Table 2 the items identified as being most deficient and most important were, income tax effect accounting. Also found to be important were the items accounting for business combinations and accounting for intangibles however the information deficiency was not considered to be as high. An interesting finding is that two items, accounting for leases and operations of conglomerates actually resulted in negative information deficiency this is presumably due to long period over which these accounting standards have been subjected to close scrutiny. With regards to accounting for leases there is currently a move to change the international accounting standard so that all leases are recognised and this would simplify the process of determining what is or is not to be recognised. The most important item was identified as income tax effect accounting and this may be due to the change to this accounting method that was introduced by the adoption of the international accounting standard. 
Table 2. Current Problems in Financial Reporting

\begin{tabular}{||l|l|l||}
\hline & $\begin{array}{l}\text { Information } \\
\text { deficiency }\end{array}$ & Importance \\
\hline $\begin{array}{l}\text { Accounting for business combinations } \\
\text { Calculation of Earnings Per Share }\end{array}$ & 0.9 & 4.6 \\
Operations of Conglomerates & 1.4 & 3.1 \\
Accounting for Leases & -0.8 & 2.6 \\
Accounting for Intangibles & -0.9 & 1.6 \\
Superannuation (Pension) Plans & 0.7 & 4.5 \\
Income Tax Effect Accounting & 0.6 & 3.9 \\
\hline
\end{tabular}

Under the heading proposals for improved financial reporting presented in Table 3 the items identified as being most important and most deficient were the use of fair market values, executory contracts, and accounting for human resources. With regards to the use of fair market values the international accounting standard allows for the choice to be made between using historical cost or fair market value for measuring assets which would explain why this is perceived as being the most important. An explanation for the perception that the information is not as deficient for market value measurement may be that it had been incorporated in a number of accounting standards in Australia prior to the adoption of the international accounting standards and as such there is a high level of acceptance and information available. In contrast, accounting for human resources has not been explored fully and remains unresolved in terms of agreement for a possible accounting standard. The item identified as being the most important was use of fair market values and this may be due to the changes which came with the international accounting standards. The method of dealing with fair market values would seem to be causing some concern as it stems from the requirement to have made a choice between historical cost or fair market value as the method to be used by an organisation. 
Table 3. Proposals for Improved Financial Reporting

\begin{tabular}{||l|l|l||}
\hline & $\begin{array}{l}\text { Information } \\
\text { deficiency }\end{array}$ & Importance \\
\hline $\begin{array}{l}\text { Accounting for Human Resources } \\
\text { Disclosure of Operating Statistics }\end{array}$ & 3.2 & 3.5 \\
Budgetary Disclosure on Financial Reports & 0.8 & 2.9 \\
Disclosure of Rate of Return on Investment & 0.7 & 2.6 \\
Subjective Probability Statements in Financial & 1.1 & 2.5 \\
Reporting & 1.5 & 5.1 \\
The use of Fair Market Values & 1.8 & 4.3 \\
Executory Contracts & & \\
\hline
\end{tabular}

Under the heading other problems in financial reporting the items presented in Table 4 the items identified as being most important and most deficient were treatment of prior period adjustments, definition of equity versus liability, impairment testing, and definition of reporting entity. There are a number of items deemed to be important; the two that rank equally are definition of equity versus liability and treatment of prior period adjustments and these can both be traced to changes that were introduced by the adoption of the international accounting standards. Firstly, there is debate that certain items which have been traditionally classified as equity may or should be reclassified as a liability (for example, preference shares). Secondly, the treatment of prior period adjustments as specified in the international accounting standards is a reversal of the long held doctrine that the past reported figures could not be changed, that is that the closing balance form the previous year would and should be the opening balance for the next year. That the new standard has effectively overturned that approach has obviously caused some concern among certain members of the accounting profession. 
Table 4. Other Problems in Financial Reporting

\begin{tabular}{||l|l|l||}
\hline & $\begin{array}{l}\text { Information } \\
\text { deficiency }\end{array}$ & Importance \\
\hline Impairment testing & 1.1 & 5.3 \\
Definition of Equity vs Liability & 1.2 & 5.4 \\
Treatment of Prior Period Adjustments & 1.9 & 5.4 \\
Footnote Disclosures & 0.2 & 3.1 \\
Definition of a Reporting Entity & 1.1 & 5.2 \\
Definition of Assets & 0.3 & 4.8 \\
\hline
\end{tabular}

\section{Conclusion}

The emphasis placed upon achieving global harmonization of financial reporting has lead to the adoption of the international accounting standards either in full, as is the case in Australia, or in some form of modified acceptance. This harmonization process presented many challenges and is still the subject of debate regarding the controversial merits of handing over the responsibilities of accounting standard setting to an organisation outside the regulatory framework of the home country. The attitudes of the accounting professionals surveyed indicates that there are items which have not been satisfactorily dealt with under the new financial reporting regime.The perceptions of the accounting professionals provide a form of assessment about the relative importance of the various accounting issues and the adequacy of the information that has so far been provided.

In regards to the items which were identified as problems (Table 1) there appears to be a link. The link may be made on the basis that the most important issue is uniformity in financial reporting then the next two with equal importance are definition of income (revenue) and timing of revenue recognition. This may be interpreted as indicating that these items combined are in need of urgent attention. With regards to current problems in financial reporting the stand out item (Table 2) is income tax effect accounting with the highest score for both information deficiency and importance and this may be a direct result of the changes to the method adopted under the international accounting standards which differed significantly from the Australian method previously used. Turning to the proposed areas for improved financial reporting (Table 3) the most important item was the use of fair market values. Although this area was one which had previously been addressed in Australia the approach taken by the international accounting standards is different and has introduced a more stringent method of annual review of the values on assets regardless of whether the 
historical cost or the fair market value has been used. With regards to the items identified as important (Table 4) there are some links with the previously identified items. For example, impairment test is related to the use of fair market value. Of the two items with the equally highest score, the definition of equity versus liability is a recent and somewhat dramatic change in financial reporting and has the potential to impact upon the liabilities of an entity to the detriment of any debt covenants. The second item treatment of prior period adjustments has the potential to result in inappropriate choices and income smoothing behaviour.

The differences between the results from this study and those reported in prior research may be explained by the changes which have occurred in Australia since to the adoption of the international accounting standards. By contrast, the USA has continued to operate under their conceptual framework and have yet to reach agreement on the level of harmonisation with regards to the international accounting standards. Future research should seek to focus on those items which continue to cause concern and have been identified as being information deficient as well as those items which have been identified as being of greater importance even if the information was not deemed to be deficient.

\section{References}

Brown P \& Tarca A. (2005). 2005 â “ Itâ TMS Here, Ready or Not: A Review of the Australian Financial Reporting Framework, Australian Accounting Review, 15(2), pp.68-78.

Chand P. \& White M. (2007). A Critique of the Influence of Globalization and convergence of accounting standards in Fiji, Critical Perspectives on Accounting 18 (x), pp.605-622. http://dx.doi.org/10.1016/j.cpa.2006.05.006

Collette P., Godfrey J. \& Hrasky S. (1998). Standard-setting in Australia: Implications of Recent Radical Reform Proposals, Australian Accounting Review, 8(2), pp.9-17.

Copeland R.M., Francia A.J., \& Strawser R.H. (1973). Students as Subjects in Behavioral Business Research, The Accounting Review, 48(2), pp.365-372.

Cooper K. \& Deo H. (2005). Recurring Cycle of Australian Corporate Reforms: â œA Never Ending Storyâ , Journal of American Academy of Business, 7(2), pp.156-163.

Cooper M., (1976). An Exact Probability Test for use with Likert-type Scales, Educational and Psychological Measurement, pp.647-655.

http://dx.doi.org/10.1177/001316447603600310

Dane F. (1990). Research Methods, Brooks/Cole Publishing Company.

Deegan C. (2010). Australian Financial Accounting 6th Edn., McGraw-Hill: Sydney.

Francia A.J, Grossman S.D., \& Strawser R.H., (1978). The Attitudes of Management Accountants, Management Accounting, November, pp.35-40. 
Francia A.J., \& Strawser R.H., (1971). Perceptions of Financial Reporting Practices by Accounting Educators: An Empirical Study, The Accounting Review, 46(2), pp.381-384.

Francia A.J. \& Strawser R.H. (1972). Attitudes of Management Accountnats on the State of the Art, Management Accounting, May, pp.21-24.

Gallery G., Cooper E. \& Sweeting J. (2008). Corporate Disclosure Quality: Lessons from Australian Companies on the Impact of Adopting International Accounting Standards, Australian Accounting Review, 18(3), pp.257-273.

Haswell S. \& Langfield-Smith I. (2008). Fifty-Seven Serious Defects in â Australianâ TM IFRS, Australian Accounting Review, 18(1), pp.46-62.

http://dx.doi.org/10.1111/j.1835-2561.2008.0006.x

Hines R.D. (1989). Financial Accounting Knowledge, Conceptual Framework Projects and the Social Construction of the Accounting Profession, Accounting, Auditing and Accountability Journal, 2(2), pp.72-92.

Hothersall D. (1985). Psychology, Charles E. Merril Publishing Company: Columbus.

Hsu L. (1979). Agreement or Disagreement of a Set of Likert-type Ratings, Educational and Psychological Measurement, pp.291-295.

http://dx.doi.org/10.1177/001316447903900205

Nachimas D. \& Nachimas C. (1976). ResearchMethods in the Social Sciences, Edward Arnold: London.

Porter L.W. (1962). Job Attitudes in Management, Journal of Applied Psychology, Vol.46, No.6, pp.375-384.

http://dx.doi.org/10.1037/h0047808

Statt D. (1981). A Dictionary of Human Behaviour, Harper \& Row, Publishers, London, 1981.

Trump G.W. \& Hendrickson H.S. (1971). Perceptions of Financial Reporting Practices by CPA's, The Journal of Accountancy, Dec. pp.84-86.

Watson D.J. (1974). Students as Surrogates in Behavioral Business Research: Some Comments, The Accounting Review, 49(3), pp. 530-533.

Watts R. \& Zimmerman J. (1978). Towards a Positive Theory of the Determinants of Accounting Standards, The Accounting Review, 53(1), pp.112-134. 


\section{Macrothink}

International Journal of Accounting and Financial Reporting ISSN 2162-3082 2011, Vol. 1, No. 1

Whittington G. (2005). The Adoption of International Accounting Standards in the European Union, European Accounting Review, 14(1), pp. 127-153.

http://dx.doi.org/10.1080/0963818042000338022

Wines G., Dagwell R. \& Windsor C. (2007). Implications of the IFRS goodwill accounting treatment, Managerial Auditing Journal, 22(9), pp.862-880.

http://dx.doi.org/10.1108/02686900710829381 